\title{
A NEW MULTIPLE HALF-DISCRETE HILBERT-TYPE INEQUALITY
}

\section{BING HE AND BICHENG YANG}

Abstract. By using the way of weight functions and technique of real analysis, a new multiple half-discrete Hilbert-type inequality with the best constant factor is given. As applications, the equivalent forms, operator expressions as well as some reverse inequalities are also considered.

Mathematics subject classification (2010): 26D15, 47A07.

Keywords and phrases: Multiple half-discrete Hilbert-type inequality, weight function, operator expression, equivalent form, reverse inequality.

\section{REFERENCES}

[1] G. H. Hardy, J. E. Littlewood, And G. Pólya, Inequalities, Cambridge University Press, Cambridge, 1934.

[2] D. S. Mitrinović, J. E. PeČARIĆ, AND A. M. FinK, Inequalities involving functions and their integrals and derivatives, Kluwer Acaremic Publishers, Boston, 1991.

[3] B. YANG, A Hilbert-type integral inequality with a non-homogeneous kernel, Journal of Xiamen University (Natural Science), 48(2)(2009), 165-169.

[4] B. YANG, On the norm of an integral operator and applications, J. Math. Anal. Appl., 321 (2006), 182-192.

[5] B. YANG, On the norm of a certain self-adjoint integral operator and applications to bilinear integral inequalities, Taiwanese Journal of Mathematics, 12 (2) (2008), 315-324.

[6] B. HE, On a Hilbert-type integral inequality with a homogeneous kernel in $R^{2}$ and its equivalent form, Journal of Inequalities and Applications, 2012, 94 (2012) doi : 10.1186/1029-242X-2012-94.

[7] B. He AND Y. LI, On several new inequalities close to Hilbert-Pachpatte's inequality, J. Ineq. in Pure and Applied Math., 7 (4) (2006), Art.154: 1-9.

[8] B. HE AND B. YANG, On a half-discrete inequality with a general homogeneous kernel, Journal of Inequalities and Applications 2012, 30 (2012) doi:10.1186/1029-242X-2012-30.

[9] B. YANG, A survey of the study of Hilbert-type inequalities with parameters, Advances in Math., 2009, 38 (3): 257-268.

[10] Q. HuAng AND B. YANG, On a multiple Hilbert-type integral operator and applications, Journal of Inequalities and Applications, Vol. 2009, Art. ID 192197: 1-13.

[11] Q. HUANG AND B. YANG, A multiple Hilbert-type integral inequality with a non-homogeneous kernel, Journal of Inequalities and Applications, 2013, 73 (2013) doi : 10.1186/1029-242X-2013-73.

[12] Y. Hong, On multiple Hardy-Hilbert integral inequalities with some parameters, Journal of Inequalities and Applications, Vol. 2006, Art. ID 94960: 1-11.

[13] I. BRnetić, M. KRnić, AND J. PeČARIĆ, Multiple Hilbert and Hardy-Hilbert inequalities with non-conjugate parameters, Bull. Austral. Math. Soc. 71 (2005), 447-457.

[14] M. KRnIĆ, Multidimensional Hilbert-type inequality on the weighted Orlicz spaces, Mediterranean J. Math. 9 (2012), 883-895.

[15] I. Perić AND P. Vuković, Hardy-Hilbert's inequalities with a general homogeneous kernel, Math. Inequal. Appl. 12 (2009), 525-536.

[16] I. PERIĆ AND P. VuKović, Hilbert-type inequalities with a product-type homogeneous kernel and Schur polynomials, J. Math. Anal. Appl. 359 (2009), 786-793.

[17] W. ZHONG AND B. YANG, On a multiple Hilbert-type integral inequality with the symmetric kernel, Journal of Inequalities and Applications, Vol. 2007, Art. ID 27962: 1-17. 
[18] B. Yang, I. Brnetić, M. KRnić, And J. PeČArić, Generalization of Hilbert and Hardy-Hilbert integral inequalities, Math. Inequal. Appl., 8, 2 (2005): 259-272.

[19] B. YANG, The norm of operator and Hilbert-type inequalities, Science Press, Beijin, 2009.

[20] J. KUANG, Introduction to real analysis, Hunan Education Press, Changsha, 1996.

[21] J. KuANG, Applied inequalities, Shangdong Science Technic Press, Jinan, 2004. 